\title{
STUDIES ON INTRAVENOUS WATER DIURESIS AND NICOTINE AND PITRESSIN ANTIDURESIS IN NORMAL SUBJECTS AND PATIENTS WITH LIVER DISEASE ${ }^{1}$
}

\author{
By STANLEY H. BERNSTEIN,2 RAYMOND E. WESTON, GEORGE ROSS, JACOB \\ GROSSMAN, IRWIN B. HANENSON, ${ }^{3}$ AND LOUIS LEITER
}

(From the Medical Division, Montefiore Hospital, New York, N. Y.)

(Submitted for publication November 5, 1952; accepted January 21, 1953)

The fluid retention of patients with liver disease, leading to edema and ascites, has generally been attributed to primary sodium retention with secondary, obligatory water retention. However, because of the impaired water diuresis following oral hydration and the increased amounts of urinary antidiuretic activity observed in such patients, several investigators (1-4) have postulated some primary change in mechanisms influencing the release, physiological effect or inactivation of the neurohypophyseal antidiuretic hormone.

White, Rubin and Leiter (5) observed that, on the average, the maximal urine flows and periods of time required to achieve peak diuresis, during infusions of $10 \mathrm{ml}$. of intravenous glucose in water per minute, were the same in patients with liver disease and subjects with normal liver function. Furthermore, intravenous administration of $0.57 \mathrm{mU}$ of Pitressin per $\mathrm{Kg}$., during such water diuresis, produced antidiuresis of equivalent degree and duration in both groups. They concluded that there was no change in the rate of inactivation of either endogenous antidiuretic hormone or this dose of exogenous antidiuretic substance in patients with liver disease. More recently, Nelson and Welt (6) have confirmed these observations on essentially similar doses of Pitressin, i.e., 2.5-100 $\mathrm{mU}$ intravenously. However, they found that when much larger doses of Pitressin were given subcutaneously to cirrhotic patients, there was delayed recovery from antidiuresis. They suggested that slower absorption of the large dose was the cause of the more prolonged antidiuresis.

\footnotetext{
1 Supported in part by grants from the National Heart Institute, U. S. Public Health Service; Martha Hall Foundation, Montefiore Hospital; Eli Lilly and Company; Wyeth, Inc.; and G. D. Searle Co.

2 Present address : Epidemiological Detachment, Sampson Air Force Base, Geneva, New York.

${ }^{3}$ Rosenstock Memorial Foundation Fellow in Medicine.
}

These observations, however, do not exclude the possibility that excessive production of endogenous posterior pituitary antidiuretic hormone $(\mathrm{ADH})$ or inadequate inactivation of larger doses of Pitressin or ADH might contribute to the retention of water in cirrhotic patients. Furthermore, the biological and chemical identity of commercial Pitressin and human endogenous posterior pituitary $\mathrm{ADH}$ has not been conclusively established. Therefore, the present studies were undertaken, using nicotine salicylate which has been demonstrated to stimulate posterior pituitary discharge of antidiuretic hormone in man (7-9). Patients with liver disease and recurring ascites on low salt diets were given very large intravenous water loads until maximum diuresis had been reached. Then, the degree and duration of the antidiuresis produced by the endogenous $\mathrm{ADH}$, released after the intravenous injection of nicotine salicylate, were compared with the antidiuresis effected by Pitressin in "physiologic" doses intravenously.

\section{EXPERIMENTAL MATERIALS AND METHODS}

The subjects were 15 patients with cirrhosis of the liver, 12 of whom had varying degrees of demonstrable ascites. Three normal young female subjects and one patient with Addison's disease, who was maintained on $4 \mathrm{mg}$. of desoxycorticosterone acetate (DCA) and $25 \mathrm{mg}$. of cortisone daily, were also studied. All the cirrhotics and one of the normal subjects were on a low ( $25 \mathrm{mEq}$.) sodium diet. Two of the cirrhotic patients were studied twice.

The recumbent subjects, in the post-absorptive state, were given 1 liter of water orally in the morning one hour before the procedure. Then, diuresis was established by the intravenous administration of 5 per cent glucose in water at a constant rate, varying in the different subjects from 15 to $20 \mathrm{ml}$. per minute. Urine collections were obtained at approximately 10 minute intervals with the aid of sterile water and air washouts through a multi-holed soft rubber catheter. Arterial blood was drawn periodically through an indwelling femoral arterial needle. 


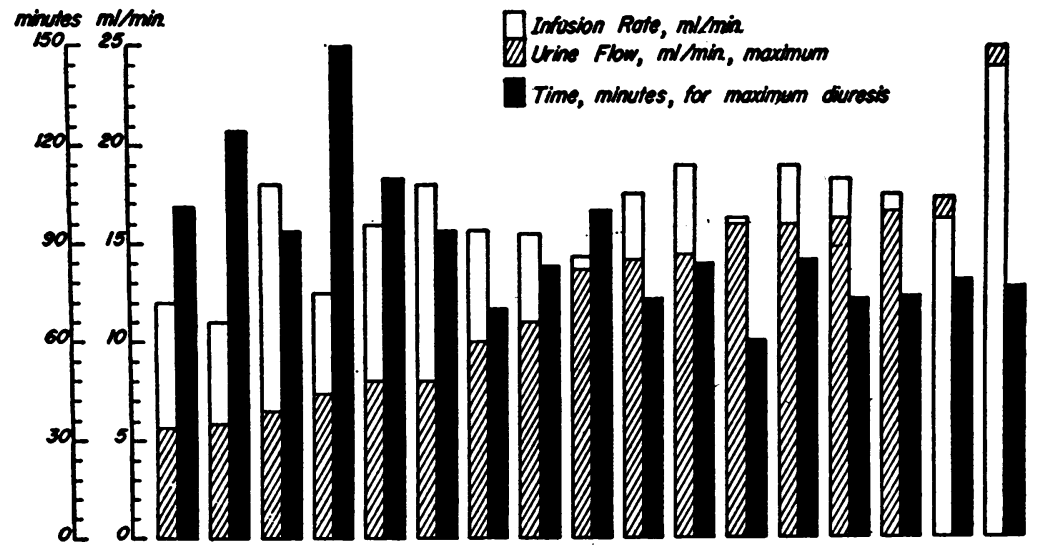

Fig. 1. Maximal Response of Cirrhotic Patients to Intrafenous HYDRATION

When urine flows reached a constant maximal value in five of the cirrhotic patients, in the three normal subjects, and in the patient with Addison's disease, 1 to 3 mg. of nicotine salicylate (50 per cent alkaloid) were injected intravenously and urines collected until the flow had returned approximately to the previous control level. Then, a dose of Pitressin estimated to produce equivalent antidiuresis, 10 to $20 \mathrm{mU}$, was given intravenously and the resulting antidiuresis similarly measured. In several patients more than one dose of Pitressin was necessary to approximate the effect of the nicotine. To obviate the influence of any prolonged pharmacological effect, the order of injection of the two drugs was reversed in several instances. The procedure was repeated in two of the cirrhotic patients on subsequent days in order to test reproducibility of the observations.

Blood and urine samples were analyzed by the following methods: creatinine-like chromogen by Peter's modification of the Folin method (10), sodium and potassium with a lithium internal standard flame photometer,

TABLE I

Clinical status, creatinine clearance, and data on infusion diuresis of cirrhotic patients and subjects without liver disease

\begin{tabular}{|c|c|c|c|c|c|c|c|}
\hline \multirow[b]{2}{*}{ Patient } & \multirow[b]{2}{*}{ Age } & \multirow[b]{2}{*}{ Diagnosis } & \multirow[b]{2}{*}{$\begin{array}{c}\text { Degree of } \\
\text { ascites }\end{array}$} & \multirow[b]{2}{*}{$\begin{array}{l}\text { Infusion } \\
\text { rate }\end{array}$} & \multicolumn{2}{|c|}{ Maximal diuresis* } & \multirow[b]{2}{*}{$\begin{array}{l}\text { Creatinine } \\
\text { clearance }\end{array}$} \\
\hline & & & & & Urine flow & $\begin{array}{l}\text { Time to } \\
\text { achieve }\end{array}$ & \\
\hline $\begin{array}{l}\text { R. Z. } \\
\text { R. W. } \\
\text { R. C. } \\
\text { R. C. }\end{array}$ & $\begin{array}{l}40 \\
49 \\
38 \\
38\end{array}$ & $\begin{array}{l}\text { Cirrhosis } \\
\text { Cirrhosis } \\
\text { Cirrhosis } \\
\text { Cirrhosis }\end{array}$ & $\begin{array}{l}4+ \\
4+ \\
4+ \\
4+\end{array}$ & $\begin{array}{c}\text { ml./min. } \\
19.0 \\
18.0 \\
18.7 \\
16.0\end{array}$ & $\begin{array}{c}\text { ml./min. } \\
15.9 \\
6.50 \\
8.00 \\
8.00\end{array}$ & $\begin{array}{r}\min . \\
85 \\
94 \\
97 \\
110\end{array}$ & $\begin{array}{c}\text { ml./min. } \\
31.4 \\
56\end{array}$ \\
\hline $\begin{array}{l}\text { H. W. } \\
\text { M. B. } \\
\text { J. V. } \\
\text { T. Mc. }\end{array}$ & $\begin{array}{l}48 \\
53 \\
53 \\
45\end{array}$ & $\begin{array}{l}\text { Cirrhosis } \\
\text { Cirrhosis } \\
\text { Cirrhosis } \\
\text { Cirrhosis }\end{array}$ & $\begin{array}{l}3+ \\
3+ \\
3+ \\
3+\end{array}$ & $\begin{array}{l}15.5 \\
16.5 \\
19.0 \\
12.0\end{array}$ & $\begin{array}{c}9.60 \\
10.9 \\
14.4 \\
5.58\end{array}$ & $\begin{array}{r}70 \\
83 \\
84 \\
101\end{array}$ & $\begin{array}{r}84 \\
102 \\
30\end{array}$ \\
\hline $\begin{array}{l}\text { J. V. } \\
\text { B. F. } \\
\text { B. F. } \\
\text { M. } \dot{M} .\end{array}$ & $\begin{array}{l}53 \\
42 \\
42 \\
40\end{array}$ & $\begin{array}{l}\text { Cirrhosis } \\
\text { Cirrhosis } \\
\text { Cirrhosis } \\
\text { Cirrhosis }\end{array}$ & $\begin{array}{l}2+ \\
2+ \\
2+ \\
2+\end{array}$ & $\begin{array}{l}17.4 \\
17.5 \\
18.2 \\
16.6\end{array}$ & $\begin{array}{l}16.4 \\
14.2 \\
15.3 \\
19.0\end{array}$ & $\begin{array}{l}74 \\
73 \\
73 \\
79\end{array}$ & $\begin{array}{r}85 \\
101 \\
104\end{array}$ \\
\hline $\begin{array}{l}\text { D. C. } \\
\text { R. F. }\end{array}$ & $\begin{array}{l}28 \\
45\end{array}$ & $\begin{array}{l}\text { Cirrhosis } \\
\text { Hemochromatosis }\end{array}$ & $\begin{array}{l}1+ \\
1+\end{array}$ & $\begin{array}{l}12.5 \\
16.1\end{array}$ & $\begin{array}{l}7.25 \\
16.9\end{array}$ & $\begin{array}{r}150 \\
60\end{array}$ & \\
\hline $\begin{array}{l}\text { A. C. } \\
\text { W. M. } \\
\text { O. S. } \\
\text { F. E. }\end{array}$ & $\begin{array}{l}45 \\
64 \\
75 \\
42\end{array}$ & $\begin{array}{l}\text { Cirrhosis } \\
\text { Cirrhosis } \\
\text { Cirrhosis } \\
\text { Addison's Dis. }\end{array}$ & $\begin{array}{l}\mathbf{0} \\
\mathbf{0} \\
\mathbf{0} \\
\mathbf{0}\end{array}$ & $\begin{array}{l}24.2 \\
14.2 \\
11.0 \\
17.2\end{array}$ & $\begin{array}{c}26.0 \\
13.6 \\
5.88 \\
12.6\end{array}$ & $\begin{array}{r}77 \\
102 \\
125 \\
60\end{array}$ & 72 \\
\hline $\begin{array}{l}\text { M.S. } \\
\text { E. S. } \\
\text { M. J. }\end{array}$ & $\begin{array}{l}40 \\
23 \\
29\end{array}$ & $\begin{array}{l}\text { Normal } \\
\text { Normal } \\
\text { Normal }\end{array}$ & $\begin{array}{l}\mathbf{0} \\
\mathbf{0} \\
\mathbf{0}\end{array}$ & $\begin{array}{l}18.6 \\
17.7 \\
17.5\end{array}$ & $\begin{array}{l}20.2 \\
14.1 \\
14.3\end{array}$ & $\begin{array}{l}67 \\
85 \\
85\end{array}$ & $\begin{array}{l}84 \\
81 \\
76\end{array}$ \\
\hline
\end{tabular}

\footnotetext{
* During initial glucose infusion prior to administration of any antidiuretic materials.
} 
chloride by the Van Slyke-Hiller modification of Sendroy's iodometric method (11), and glucose by an application of Somogyi's blood sugar method (12). Blood eosinophile counts were measured by a modification of Randolph's method (13).

\section{RESULTS}

\section{Water Excretion}

Figure 1 graphically presents the rate of infusion in each cirrhotic patient, the urine flows during peak diuresis and the time required to achieve maximal urine flow.

The ability of 10 of these patients to excrete large quantities of water during water loading is quite evident. At times the urine flows closely approximated, or even exceeded, the infusion rate. The maximal urine flow in five cirrhotic patients was less than $8 \mathrm{ml}$. per minute, despite much greater infusion rates. Of this group, one patient had known renal disease, three were accumulating fluid rapidly and had considerable ascites, and one was highly apprehensive and emotionally disturbed during the procedure. The time required to achieve maximal urine flows averaged 90 minutes.

Table I contains comparable data on the normal group and the Addisonian patient who was main- tained on DCA and cortisone. These subjects achieved maximal urine flows comparable to the rate of infusion. The time required to achieve peak diuresis averaged 77 minutes, a value not significantly different from that of the 10 cirrhotics exhibiting good diuresis.

Because only traces of glycosuria were observed in occasional patients, the increased urine flows do not represent osmotic diureses.

\section{Nicotine-Pitressin Antidiuresis}

Figure 2 illustrates a typical procedure on a patient with cirrhosis and ascites. In the cirrhotics, the urine flow fell to a mean of $2.89 \mathrm{ml}$. per minute following nicotine and of $2.26 \mathrm{ml}$. per minute following Pitressin. The average duration of antidiuresis was 63 minutes after nicotine and 58 minutes after Pitressin.

In Table II are presented the results on the cirrhotic patients, the normal subjects, and the patient with Addison's disease. In the patients without liver disease, the duration of antidiuresis was 52 minutes following nicotine and 54 minutes following Pitressin. The intensity and duration of antidiuresis produced by the two drugs were essentially the same in all patients.

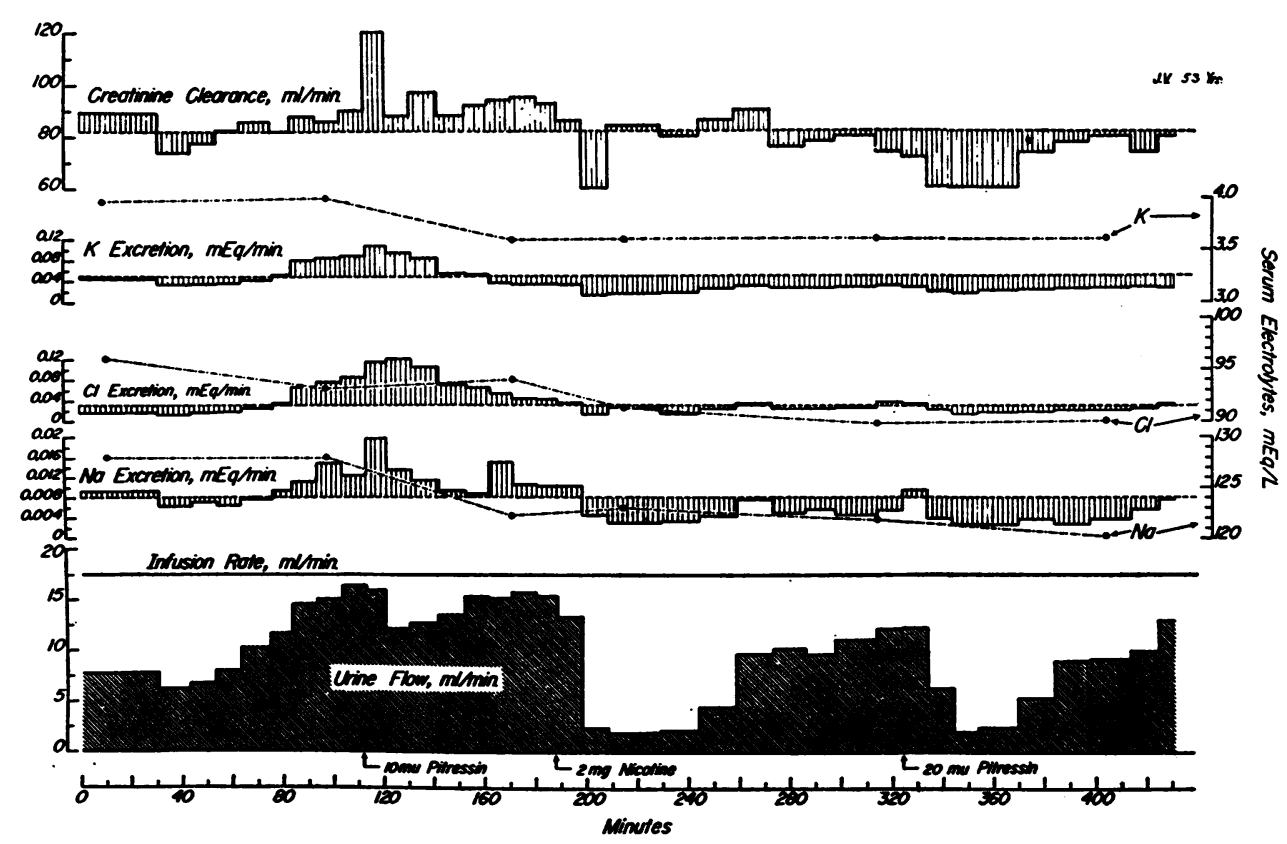

Fig. 2. Comparison of Pitressin and Nicotine-Induced Antidiuresis in Intravenously Hydrated Cirreotic Patient on Low Salt Diet 
TABLE II

Comparison of nicotine and Pitressin anti-diuresis in cirrhotic patients and subjects without liver disease

\begin{tabular}{|c|c|c|c|c|c|c|c|}
\hline Patient & Diagnosis & Smoking & Drug & Dose & $\begin{array}{l}\text { Water diuresis } \\
\text { Max. urine fl.* }\end{array}$ & $\begin{array}{c}\text { Antic } \\
\text { Minimal } \\
\text { U.F. } \dagger\end{array}$ & $\begin{array}{l}\text { uresis } \\
\text { Duration }\end{array}$ \\
\hline H. W. & Cirrhosis & 0 & $\begin{array}{l}\text { Nicotine } \\
\text { Pitressin }\end{array}$ & $\begin{array}{l}2 \mathrm{mg} . \\
10 \mathrm{mU}\end{array}$ & $\begin{array}{c}\text { ml. } / \min . \\
8.50 \\
7.50\end{array}$ & $\begin{array}{c}\text { ml./min. } \\
3.70 \\
1.82\end{array}$ & $\begin{array}{c}\min . \\
50 \\
44\end{array}$ \\
\hline M. B. & Cirrhosis & $\mathbf{0}$ & $\begin{array}{l}\text { Nicotine } \\
\text { Pitressin }\end{array}$ & $\begin{array}{l}2 \mathrm{mg} . \\
10 \mathrm{mU}\end{array}$ & $\begin{array}{l}10.9 \\
10.7\end{array}$ & $\begin{array}{l}1.20 \\
2.00\end{array}$ & $\begin{array}{l}62 \\
44\end{array}$ \\
\hline J. V. & Cirrhosis & 0 & $\begin{array}{l}\text { Nicotine } \\
\text { Pitressin }\end{array}$ & $\begin{array}{l}2 \text { mg. } \\
20 \text { mU }\end{array}$ & $\begin{array}{l}20.0 \\
14.4\end{array}$ & $\begin{array}{l}2.38 \\
2.71\end{array}$ & $\begin{array}{l}78 \\
58\end{array}$ \\
\hline J. V. & Cirrhosis & 0 & $\begin{array}{l}\text { Nicotine } \\
\text { Pitressin }\end{array}$ & $\begin{array}{l}2 \mathrm{mg} . \\
20 \mathrm{mU}\end{array}$ & $\begin{array}{l}15.7 \\
12.2\end{array}$ & $\begin{array}{l}2.00 \\
2.00\end{array}$ & $\begin{array}{l}74 \\
60\end{array}$ \\
\hline B. F. & Cirrhosis & 0 & $\begin{array}{l}\text { Nicotine } \\
\text { Pitressin }\end{array}$ & $\begin{array}{l}3 \mathrm{mg} \\
10 \mathrm{mU}\end{array}$ & $\begin{array}{l}15.4 \\
15.3\end{array}$ & $\begin{array}{l}2.40 \\
2.60\end{array}$ & $\begin{array}{l}76 \\
63\end{array}$ \\
\hline B. F. & Cirrhosis & $\mathbf{0}$ & $\begin{array}{l}\text { Nicotine } \\
\text { Pitressin }\end{array}$ & $10 \overline{\mathrm{mU}}$ & $\begin{array}{l}15.4 \\
14.2\end{array}$ & $\overline{2.60}$ & $\overline{60}$ \\
\hline M. M. & Cirrhosis & + & $\begin{array}{l}\text { Nicotine } \\
\text { Pitressin }\end{array}$ & $\begin{array}{l}3 \mathrm{mg} \\
20 \mathrm{mU}\end{array}$ & $\begin{array}{l}19.0 \\
17.2\end{array}$ & $\begin{array}{l}5.70 \\
2.00\end{array}$ & $\begin{array}{l}38 \\
79\end{array}$ \\
\hline F. E. & Addison's Dis. & 0 & $\begin{array}{l}\text { Nicotine } \\
\text { Pitressin }\end{array}$ & $\begin{array}{l}2 \mathrm{mg} . \\
5 \mathrm{mU}\end{array}$ & $\begin{array}{l}12.6 \\
17.9\end{array}$ & $\begin{array}{l}6.80 \\
6.00\end{array}$ & $\begin{array}{l}44 \\
65\end{array}$ \\
\hline M. S. & Normal & 0 & $\begin{array}{l}\text { Nicotine } \\
\text { Pitressin }\end{array}$ & $\begin{array}{l}2 \text { mg. } \\
10 \text { mU }\end{array}$ & $\begin{array}{l}25.0 \\
20.2\end{array}$ & $\begin{array}{l}9.20 \\
7.75\end{array}$ & $\begin{array}{l}37 \\
35\end{array}$ \\
\hline E. S. & Normal & + & $\begin{array}{l}\text { Nicotine } \\
\text { Pitressin }\end{array}$ & $\begin{array}{l}3 \mathrm{mg} . \\
10 \mathrm{mU}\end{array}$ & $\begin{array}{l}13.9 \\
14.1\end{array}$ & $\begin{array}{l}6.56 \\
1.75\end{array}$ & $\begin{array}{l}60 \\
60\end{array}$ \\
\hline M. J. & Normal & + & $\begin{array}{l}\text { Nicotine } \\
\text { Pitressin }\end{array}$ & $\begin{array}{l}3 \mathrm{mg} \\
10 \mathrm{mU}\end{array}$ & $\begin{array}{l}14.4 \\
14.3\end{array}$ & $\begin{array}{l}4.90 \\
1.66\end{array}$ & $\begin{array}{l}67 \\
60\end{array}$ \\
\hline
\end{tabular}

* Just prior to giving Pitressin or nicotine.

† U. F. = Urine flow.

\section{Urinary Excretion annd Serum Concentra- tions of Electrolytes}

Little change was noted in urinary electrolyte excretion during the glucose in water infusions, despite the large changes in water excretion. An increase in urinary sodium, chloride and potassium excretions was noted during the early periods of hydration (cf. Figure 2) in all the patients except the three seriously ill cirrhotic patients, who exhibited little diuresis on water loading. This may represent normal diurnal variation in electrolyte excretion, since the increase occurred at the time of expected matutinal rise (14). The other three, sicker patients may have had the reported reversal of the typical diurnal tide (15).

\section{DISCUSSION}

The present data on the time for attainment of peak diuresis during intravenous hydration and the duration of antidiuresis produced by "physiologic" doses of Pitressin in patients with and without liver disease agree with previously reported observations $(5,6)$. Despite the somewhat smaller dosage of Pitressin used in this study, the duration of the antidiuretic effect was the same in both groups. Thus, in these cirrhotic patients there was no evidence of either increased renal tubular sensitivity to, or of decreased inactivation of, exogenous antidiuretic hormone at this dosage.

Since the time necessary to achieve maximal diuresis was similar in the cirrhotic and normal subjects, inactivation of circulating endogenous $\mathrm{ADH}$ apparently occurred at the same rate in both groups, once posterior pituitary discharge had been inhibited via osmoreceptors and possibly volume receptors ${ }^{4}(16)$. Such complete inhibition

4 The failure to observe greater increase in electrolyte excretion during maximal diuresis than would be 
suggests that the mechanisms regulating $\mathrm{ADH}$ release, if contributing at all to the fluid retention in these patients, still respond to these excessive water loads. However, in cirrhotic patients, as in cardiacs (17), acute antidiuretic mechanisms may be activated, under certain circumstances, which lead to water retention per se, despite expansion of extracellular fluid and hyponatremia. It remains to be established whether or not such sustained production of antidiuretic hormone is the responsible mechanism in these cases.

That nicotine acts to stimulate posterior pituitary secretion of antidiuretic hormone is well known. Burn, Truelove and Burn in 1945 (7) noted that $0.1 \mathrm{mg}$. of nicotine suppressed the urine flow in the hydrated rat but not in hypophysectomized rats maintained on anterior pituitary extract, and that in human subjects cigarette smoking produced similar inhibition of water diuresis. Walker subsequently also reported that cigarette smoking and intravenous injections of nicotine stimulate $\mathrm{ADH}$ discharge in normal man (8). Chalmers and Lewis (18) and Cates and Garrod (19) have recently suggested that the failure of nicotine to affect urine flow in a hydrated patient may be a positive test for diabetes insipidus. The equivalent antidiuresis observed in both our cirrhotic patients and normal subjects following nicotine salicylate and Pitressin suggests that endogenous $\mathrm{ADH}$ and aqueous Pitressin are physiologically similar in this respect. Moreover, it indicates that under the conditions of these studies the posterior pituitary of the cirrhotic patients responded physiologically but not excessively to a standard pharmacological stimulus.

The transient and inconstant changes in endogenous creatinine clearance occurring in the cirrhotic and normal subjects after Pitressin and nicotine probably reflect errors in collection due to changes in urine flow. Such an interpretation is consistent with, the established view that the antidiuresis is largely independent of changes in filtration.

Three cirrhotic patients (R. C., R. W., T. Mc. in Table I) had much lower endogenous creatinine clearances than the patients who exhibited good diuresis. These three patients were extremely

expected on the basis of diurnal variation suggests that volume receptor inhibition may not have been of significance. ill and were accumulating ascitic fluid rapidly. Therefore, their poor diuretic response may not be related specifically to antidiuretic hormone, but may be a consequence of impaired renal hemodynamics, in part due to mechanical compression of the renal veins and ureters by the large amount of fluid accumulated in the abdomen. In addition, if fluid were rapidly transferred to the peritoneal cavity during the glucose infusions, little expansion of the effective circulating volume would occur. Consequently, inhibition of volume receptors, if these were overactive, might not have been achieved.

Since blood eosinophil counts, taken at intervals for several hours after nicotine and Pitressin administration, did not change significantly in either group of patients, discharge of adrenal cortical hormone probably did not occur during these procedures. In this connection, it is interesting that the treated patient with Addison's disease also gave a typical, normal response to both Pitressin and nicotine.

The factors initiating salt and water retention in patients with cirrhosis of the liver are still obscure. Whenever the delicate balance of forces regulating electrolyte and water excretion in such patients is upset, there may be intensification of a number of mechanisms promoting fluid retention. When this occurs in patients on very restricted salt intakes, primary retention of water without sodium may result, leading to weight gain and hyponatremia, similar to that we have observed in edematous cardiacs (20). Although it is possible that sustained production of antidiuretic hormone, in the face of dilution of the body fluids, may be responsible for this water retention (21), at present, determination of the activating mechanisms or the precise role of the neurohypophysis in this process is difficult.

The present data contain no evidence of decreased inactivation, persistent hypersecretion, or increased renal tubular effects of endogenous $\mathrm{ADH}$ in our edematous cirrhotics. However, the acute occurrence of water retention in cirrhotics would suggest that a similar process may contribute to their usual, more chronic, fluid retention. An accurate method for measuring circulating $\mathrm{ADH}$ at physiologically effective blood levels is required to settle this problem. 


\section{SUMMARY AND CONCLUSIONS}

1) Seven of 11 patients with liver disease and varying degrees of ascites achieved a maximal urine flow of 9.6 to $19.0 \mathrm{ml}$. per minute, in response to the intravenous infusion of 5 per cent glucose solution at rates of 12.0 to $19.0 \mathrm{ml}$. per minute. Creatinine clearances were reduced to 31.4 to $56 \mathrm{ml}$. per minute in three of the four patients with smaller peak diuresis, in whom these measurements were made.

2) The intravenous injections of 1 to $3 \mathrm{mg}$. of nicotine salicylate in intravenously hydrated cirrhotic and normal subjects produced an antidiuretic response equivalent in degree and duration to that resulting from the intravenous injection of 5 to $20 \mathrm{mU}$ of Pitressin in the same subjects.

3) Ten cirrhotic patients with good diuresis required an average of 79 minutes to achieve maximal diuresis. This normal value points against hypersecretion or impaired inactivation of $\mathrm{ADH}$ in these patients, eight of whom had ascites.

4) The essentially similar antidiuretic response of cirrhotic patients and normal subjects to intravenous nicotine salicylate and Pitressin (endogenous and exogenous $\mathrm{ADH}$ ) seems to exclude increased renal tubular sensitivity to $\mathrm{ADH}$ in cirrhosis of the liver. The equivalent duration of this antidiuresis in cirrhotic and normal subjects is evidence against abnormal inactivation of $\mathrm{ADH}$ in the former.

5) These studies confirm the absence of significant changes in endogenous creatinine clearance and in urinary electrolyte excretion after injection of physiological amounts of Pitressin or endogenous $\mathrm{ADH}$ in the water-loaded subject.

6) The failure to achieve adequate water diuresis in certain cirrhotic patients may be attributed in part to abnormal renal hemodynamics.

\section{REFERENCES}

1. Ralli, E. P., Robson, J. S., Clarke, D., and Hoagland, C. L., Factors influencing ascites in patients with cirrhosis of the liver. J. Clin. Invest., 1945, 24, 316.

2. Adlersberg, D., and Fox, C. L., Jr., Changes of the water tolerance test in hepatic disease. Ann. Int. Med., 1943, 19, 642.

3. Robinson, F. H., Jr., and Farr, L. E., The relation between clinical edema and the excretion of an antidiuretic substance in the urine. Ann. Int. Med., $1940,14,42$.

4. Labby, D. H., and Hoagland, C. L., Water storage and the movements of body fluids and chlorides during acute liver disease. J. Clin. Invest., 1947, 26, 343.

5. White, A. G., Rubin, G., and Leiter, L., Studies in edema. III. The effect of pitressin on the renal excretion of water and electrolytes in patients with and without liver disease. J. Clin. Invest., 1951, 30, 1287.

6. Nelson, W. P., III, and Welt, L. G., The effects of pitressin on the metabolism and excretion of water and electrolytes in normal subjects and patients with cirrhosis and ascites. J. Clin. Invest., 1952, 31, 392.

7. Burn, J. H., Truelove, L. H., and Burn, I., The antidiuretic action of nicotine and of smoking. Brit. M. J., 1945, 1, 403.

8. Walker, J. M., The effect of smoking on water diuresis in man. Quart. J. Med., 1949, n.s. 18, 51.

9. Burn, G. P., and Grewal, R. S., The antidiuretic response to and excretion of pituitary (posterior lobe) extract in man, with reference to the action of nicotine. Brit. J. Pharmacol., 1951, 6, 471.

10. Peters, J. H., The determination of creatinine and creatine in blood and urine with the photoelectric colorimeter. J. Biol. Chem., 1942, 146, 179.

11. Van Slyke, D. D., and Hiller, A., Application of Sendroy's iodometric chloride titration to proteincontaining fluids: J. Biol. Chem., 1947, 167, 107.

12. Somogyi, M., (a) A new reagent for determination of sugars. (b) Determination of blood sugar. J. Biol. Chem., 1945, 160, 61 and 69.

13. Randolph, T. G., Blood studies in allergy. The direct counting chamber determination of eosinophiles by propylene glycol aqueous stains. J. Allergy, 1944, 15, 89.

14. Stanbury, S. W., and Thomson, A. E., Diurnal variations in electrolyte excretion. Clin. Sc., 1951, 10, 267.

15. Goldman, R., Studies in diurnal variation of water and electrolyte excretion: nocturnal diuresis of water and sodium in congestive heart failure and cirrhosis of the liver. J. Clin. Invest., 1951, 30, 1191.

16. Peters, J. P., Sodium, water, and edema. J. Mt. Sinai Hosp., 1950, 17, 159.

17. Weston, R. E., Borun, E. R., Grossman, J., Guerin, H. A., Ullmann, T. D., Wolfman, M., and Leiter, L., Acute hyponatremia due to water retention in congestive heart failure. Proc. of the 25th Scientific Session, April 18-19, 1952, Am. Heart Association, N. Y., p. 13.

18. Lewis, A. A. G., and Chalmers, T. M., A nicotine test for the investigation of diabetes insipidus. Clin. Sc., 1951, 10, 137.

19. Cates, J. E., and Garrod, O., The effect of nicotine on urinary flow in diabetes insipidus. Clin. Sc., 1951, 10, 146.

20. Weston, R. E., Hanenson, I. B., Grossman, J., Wolfman, M., Aaron, R. S., and Leiter, L., Unpublished observations.

21. Nelson W. P., III, Rosenbaum, J. D., and Strauss, M. B., Hyponatremia in hepatic cirrhosis following paracentesis. J. Clin. Invest., 1951, 30, 738. 